\title{
Geographical and altitudinal population genetic structure of two dung fly species with contrasting mobility and temperature preference
}

\author{
U Kraushaar ${ }^{1}$, J Goudet ${ }^{2}$ and WU Blanckenhorn ${ }^{1}$ \\ Zoologisches Museum, Universität Zürich-Irchel, Winterthurerstrasse 190, CH-8057 Zürich, Switzerland
}

\begin{abstract}
Local adaptation of populations requires some degree of spatio-temporal isolation. Previous studies of the two dung fly species Scathophaga stercoraria and Sepsis cynipsea have revealed low levels of geographic and altitudinal genetic differentiation in quantitative life history and morphological traits, but instead high degrees of phenotypic plasticity. These patterns suggest that gene flow is extensive despite considerable geographic barriers and large spatio-temporal variation in selection on body size and related traits. In this study we addressed this hypothesis by investigating genetic differentiation of dung fly populations throughout Switzerland based on the same 10 electrophoretic loci in each species. Overall, we found no significant geographic differentiation of populations for either species. This is inconsistent with the higher rates of gene flow expected due to better flying
\end{abstract}

capacity of the larger S. stercoraria. However, heterozygote deficiencies within populations indicated structuring on a finer scale, seen for several loci in S. cynipsea, and for the locus PGM (Phosphoglucomutase) in $S$. stercoraria. Additionally, $S$. cynipsea showed a tendency towards a greater gene diversity at higher altitudes, mediated primarily by the locus MDH (malate dehydrogenase), at which a second allele was only present in populations above 1000 $\mathrm{m}$. This may be caused by increased environmental stress at higher altitudes in this warm-adapted species. MDH might thus be a candidate locus subject to thermal selection in this species, but this remains to be corroborated by direct evidence. In S. stercoraria, no altitudinal variation was found. Heredity (2002) 89, 99-106. doi:10.1038/sj.hdy.6800097

Keywords: allozymes; altitude; electrophoresis; genetic differentiation; Scathophaga stercoraria; Sepsis cynipsea

\section{Introduction}

Local adaptation of populations requires some degree of spatial or temporal isolation, that is, limited gene flow. Migration rates of individuals can be assessed via markrecapture studies (Manly, 1985), but this direct approach is cumbersome and unfeasible with small organisms such as insects. One alternative is a population genetic approach, by which rates of gene flow between populations can be estimated indirectly from the degree of population differentiation at putatively neutral genetic markers (Wright, 1943, 1951). The study of protein variation using electrophoresis is the classic method (Berg, 1997; Eanes, 1999).

The yellow dung fly Scathophaga stercoraria and Sepsis cynipsea are the most common and abundant dung flies in Europe, at least in part because both are specialized on cow dung, which abounds in agricultural landscapes (Gorodkov, 1984; Zuska and Pont, 1984). In Switzerland,

Correspondence: WU Blanckenhorn, Zoologisches Museum, Universität Zürich-Irchel, Winterthurerstrasse 190, CH-8057 Zürich, Switzerland. E-mail:wolfman@zoolmus.unizh.ch

${ }^{2}$ Present address: Institut de Zoologie et d'Ecologie Animale, Bâtiment de Biologie, Université de Lausanne, CH-1015 LausanneDorigny, Switzerland

Received 28 September 2001; accepted 10 March 2002 both species occupy environmentally heterogeneous habitats, ranging from the lowlands to the mountaintops close to the timberline (Blanckenhorn, 1997a). Previous studies of both species have demonstrated equally low levels of geographic and altitudinal genetic differentiation in quantitative life history and morphological traits such as fecundity, development time, growth rate, diapause and adult emergence, and revealed high degrees of phenotypic plasticity in response to key environmental variables such as temperature, photoperiod or resource availability (Blanckenhorn, 1997a,b, 1998a,b; Blanckenhorn et al, 2001). This suggests that gene flow preventing local adaptation is extensive despite considerable geographic barriers (ie, high mountains) and spatio-temporal variation in selection on these traits in local populations (Blanckenhorn, 1998a; Blanckenhorn et al, 1999; Jann et al, 2000; Kraushaar and Blanckenhorn, 2002). Here we address this hypothesis by investigating genetic differentiation of dung fly populations throughout Switzerland based on the same 10 electrophoretic loci in each species.

Differences in the degree of genetic differentiation between the two species can be expected, based on differences in their morphology and geographic distribution. First, unpublished field and laboratory observations including tethered-flight experiments indicate that the much larger, house-fly-sized yellow dung fly flies much faster and longer than the small, ant-sized S. cynipsea. 
This would facilitate migration and thus gene exchange between populations. One might therefore expect a lower degree of geographic genetic differentiation among $S$. stercoraria populations than among $S$. cynipsea populations. Second, the distribution of yellow dung flies, as well as other species of this genus, up to Iceland reveals a preference for colder temperatures (Gorodkov, 1984). Both larvae and adults are very sensitive to heat (Ward and Simmons, 1990; Blanckenhorn, 1998a), and in the warmer regions of their distribution yellow dung flies typically disappear from pastures to spend the summer in the cooler forests in a physiologically quiescent state (Hammer, 1941; Parker, 1970; Gibbons, 1987; Blanckenhorn et al, 2001). Sepsis cynipsea, in contrast, like it hot: they are abundant only in summer (Blanckenhorn, 1997a; Blanckenhorn et al, 1999), and their range extends south to northern Africa (Zuska and Pont, 1984; Meier, 1996). From this one might expect that, for S. stercoraria, the cooler (but harsher) high altitude habitats would be more suitable and less stressful, whereas, for S. cynipsea, high altitude habitats would be less preferable and more stressful. Environmental stress can be expected to increase mutation rates (Hoffmann and Parsons, 1991). At the same time, particular enzymes typically used in electrophoresis may not be neutral but may have functional optima at different temperatures and are thus subject to thermal selection (Watt, 1977, 1983; Watt et al, 1985; reviewed in Huey and Kingsolver, 1989; Eanes, 1999). Indeed, this appears to be the case for the phosphoglucomutase (PGM) locus in S. stercoraria (Jann, 1997; Ward, 1998, 2000). One can therefore expect more rare and potentially thermally selected alleles in the more stressful environment for each species, ie at low altitudes for $S$. stercoraria and at high altitudes in S. cynipsea, or, at least, to find altitudinal clines in allele frequencies. In this study, we test these two expectations against the nullhypotheses of no geographic or altitudinal variation in the allozyme distribution of the two species.

\section{Methods}

\section{Study sites}

The samples were collected across Switzerland between spring 1995 and late autumn 1996. The sites range from $300 \mathrm{~m}$ to $2400 \mathrm{~m}$ above sea level. We generally considered pastures as populations. The entire sample included 34 sites for S. stercoraria and 29 sites for S. cynipsea. Due to differences in the phenology of the two species, the flies were sampled at different times throughout the season (April to October).

\section{Field and laboratory procedures}

We analysed the offspring of field-collected individuals reared in the laboratory at standard conditions. In the field we randomly collected approximately 30 pairs of the yellow dung fly and about 50 pairs of S. cynipsea. We transported the live animals to the laboratory as fast as possible. There we transferred pairs into glass vials and added a smear of dung on a filter paper as well as sugar and water ad libitum. The predatory S. stercoraria were additionally provided with Drosophila melanogastor as prey. Females immediately started to lay eggs into the dung. We transferred 10 to 15 eggs from each female to a plastic bottle containing a superabundant amount of ca. $40 \mathrm{~g}$ of cow dung (Amano, 1983), and allowed the offspring generation to develop in a climate chamber at $18^{\circ} \mathrm{C}, 60 \%$ relative humidity and a photoperiod of $12 \mathrm{~h}$ (L:D 12h:12h). At emergence we randomly chose eight individuals of either sex from different clutches from each population, and stored them at $-80^{\circ} \mathrm{C}$ for later electrophoresis. Due to this limited number of individuals, rare alleles present in any particular population were less likely to be detected.

\section{Electrophoresis}

Anesthetized S. stercoraria individuals were crushed in $150 \mu \mathrm{l}$ and those of S. cynipsea in $50 \mu \mathrm{l}$ of a Mercaptoethanol-buffer. Samples were centrifuged at $11000 \mathrm{rpm}$ for $30 \mathrm{~min}$ and stored afterwards at $-80^{\circ} \mathrm{C}$. Procedures for horizontal starch-gel electrophoresis followed those given by Murphy (1990). We assayed the same 10 allozymes in both species, permitting direct comparisons: mannose-6-phosphate isomerase (MPI) EC 5.3.1.8, glycerol-3-phosphate dehydrogenase (G3PDH) EC 1.1.1.8, glucose-6-phosphate isomerase (GPI) EC 5.3.1.9, diaphorase (DIA), phosphoglucomutase (PGM) EC 5.4.2.2, 3-hydroxybutyrate dehydrogenase (HBDH) EC 1.1.1.30, hexokinase (HK) EC 2.7.1.1, an undefined variant staining with HK (HKXY), phosphogluconate dehydrogenase (6PGDH) EC 1.1.1.44 and malate dehydrogenase (MDH) EC 1.1.1.37. GPI, G3PDH, DIA, HK, HKXY and MPI were run on a Tris-citrate electrode buffer of $\mathrm{pH} 8$, while PGM, $\mathrm{HBDH}, 6 \mathrm{PGDH}$ and MDG were run on a JRP electrode buffer of $\mathrm{pH}$ 6.3. Only six loci were polymorphic in $S$. stercoraria (MPI, G3PDH, GPI, DIA, PGM and HBDH), while all loci were polymorphic in S. cynipsea. The enzyme abbreviations are those of Shaklee et al (1990). Multiple alleles encoding the same enzyme (allozymes) were designated by consecutive numbers, with ' 1 ' denoting the slowest migrating allozyme in the anodal direction.

\section{Statistical analysis}

Genotypic and allelic compositions were estimated with the program FSTAT, Version 2.9 (Goudet, 1995). For each locus, and over all loci, deviations from random mating were assessed by means of F-statistics. To test for departure from panmixia we used permutational analysis of the null distribution of each data set. Under the null hypothesis of random mating within populations, the pairing of alleles within individuals is random. We thus allocated alleles at random, without replacement, to a randomly chosen individual within each population. $F_{\text {IS }}$ was estimated from each of 5000 random re-allocations of alleles to individuals within populations using FSTAT. We could therefore test for the significance of $F_{\text {IS }}$ if the observed value belonged to the highest $5 \%$ of the null distribution, it was deemed significant. We employed similar procedures for $F_{\mathrm{IT}}$ : under the null hypothesis of random mating all over Switzerland, we permuted alleles among individuals over the whole data set. Finally, for population differentiation quantified by $F_{\mathrm{ST}}$, we permuted individuals among populations. These randomisation schemes were used to test whether populations were differentiated using the G-statistic, shown by 
Goudet et al (1996) to be more powerful than $F_{\mathrm{ST}}$ to test for population differentiation. Standard errors for F-statistics were obtained by jackknifing among populations for per-locus estimates and among loci for overall estimates.

To test for geographic variation, we examined the correlations between matrices of pairwise genetic $\left(F_{\mathrm{ST}}\right)$ and pairwise geographic distances (Slatkin, 1993) using Mantel tests (Mantel, 1967). These were also used to test for significant correlations between genetic and geographic distances (ie, for isolation by distance). To test for altitudinal variation, we performed regressions of the total number of alleles and average gene diversity over all loci, as well as the principal component of these two variables (which are interdependent), on altitude (cf. Tables 1 and 3), separately for the species. Lastly, we used a Wilcoxon matched-pairs test to directly compare the population genetic structure (ie, $F_{\mathrm{ST}}$ and $F_{\mathrm{IS}}$ ) of both species.

\section{Results}

Of the six polymorphic loci in S. stercoraria, G3PDH proved to have the lowest variability (Table 1). F-statistics revealed no overall structure whatsoever. $F_{\mathrm{ST}}$ was close to zero for all loci and overall (Table 2). Because of this lack of geographic population structure, further investigation by means of Mantel tests were not carried out. $F_{\text {IS }}$ did not differ from zero for any locus in any individual population (not shown), nor over all loci. However, after Bonferroni corrections for multiple testing, $F_{\text {IS }}$ for PGM deviated significantly from Hardy-Weinberg equilibrium within populations over all samples (Table 2), indicating heterozygote deficiency and some further structuring within populations.

In S. cynipsea, five of the 10 loci examined proved to be highly variable (MPI, DIA, HKXY, HBDH and 6PGDH), three showed some variability (PGM, GPI and $\mathrm{MDH}$ ), and two were of rather low variability (HK and G3PDH; Table 3). We found considerable deviations from Hardy-Weinberg equilibrium (ie, significant $F_{\mathrm{IS}}$ ) within several of our alleged populations for MPI, DIA, HKXY and 6PGDH (not shown). $F_{\text {IS }}$ was also significant over all populations for MPI, DIA, PGM, HKXY, MDH and all loci combined (Table 2). $F_{\mathrm{ST}}$ was significant for MPI and $\mathrm{MDH}$ as well as for all loci combined, indicating genetic differentiation among populations, however almost entirely mediated by MDH (Table 2). A Mantel test yielded no isolation by distance (results not shown).

No difference in genetic structure was found between the two species $(P>0.2)$ when directly comparing the $F_{\mathrm{ST}}$-values obtained (Table 2 ) using a Wilcoxon matchedpairs test, contrary to expectation. However, the same test was significant for $F_{\mathrm{IS}}(P<0.02)$, the values of which were consistently greater in $S$. cynipsea than $S$. stercoraria (Table 2). These results were qualitatively the same irrespective of whether we included all 10 loci (assuming values of zero for the four loci monomorphic in $S$. stercoraria), or merely the six loci polymorphic in both species. Whereas no altitudinal variation was apparent in $S$. stercoraria $(r=0.04, P>0.5)$, mean genetic diversity ( $r=0.44, P=0.017)$ and the total number of alleles over all loci (non-significant: $r=0.27, P=0.121$ ) increased with altitude in S. cynipsea (Figure 1); the principal component combining the two (interdependent) variables was also significant ( $r=0.38, P=0.043$ ). This increase is primarily mediated by the locus MDH and, to a lesser extent, by DIA and MPI. We plot the individual variables rather than the principal component in Figure 1 because these numbers are more informative. Except for PGM, allelic diversity was generally greater in S. cynipsea (Tables 1 to 3; Figure 1)

\section{Discussion}

From our data we conclude that populations of both dung fly species are not genetically differentiated in Switzerland. Formally, a significant overall $F_{\mathrm{ST}}$ for all loci combined suggests differentiation in S. cynipsea. However, this is almost entirely mediated by MDH (Table 2), and may be caused by selection as discussed below. We also found no isolation by distance. Moreover, when directly comparing the $F_{\mathrm{ST}}$-values obtained for the same allozymes, no difference in genetic structure between the two species was found. Contrary to our expectation (see Introduction), gene flow due to dispersal is apparently equally effective in both species in preventing genetic isolation among populations, despite ubiquitous geographic barriers (ie, high mountains) and the better flying ability of the larger $S$. stercoraria. Significant gene flow preventing population differentiation by genetic drift in both species agrees well with previous findings of low degrees of geographic and altitudinal genetic differentiation in quantitative traits, potentially facilitating the evolution of phenotypic plasticity (Blanckenhorn, 1997a, 1998b).

Failure to find genetic differentiation may to some extent relate to our sampling scheme, which was conservative with regard to the null hypothesis. First, we considered pastures as populations. This is probably justified in the mountains, where pastures are large and isolated: highland populations are known to be local, as the flies typically arrive before the cows, ie, they do not migrate up with them (personal observation). In the lowlands, however, where in some regions many dairy farms are located next to each other, this may not hold. Second, because we tested only eight individuals per population, very rare alleles might not have been detected. Third, our set of allozymes was less variable overall in S. stercoraria. All this limits the statistical power to detect population differentiation (ie, significant $F_{\mathrm{ST}}$ ), perhaps more so in one species than the other. However, greater allozyme variation did not result in a significant $F_{\mathrm{ST}}$ in S. cynipsea, while $F_{\mathrm{IS}}$ was often significant (discussed below). Furthermore, for our species comparison this is a minor problem because it is based on our overall mean $F_{\mathrm{ST}}$ and $F_{\text {IS }}$ values, the estimates of which should not be affected by the different number of polymorphic loci. We therefore believe that our methods have not strongly affected our results, and that the low degree of population differentiation and the differences in allozyme variation between the species are real. It is likely that the use of finer scale, highly polymorphic, DNA markers would result in significant (albeit low) $F_{\mathrm{ST}}$, but in some way this is trivial. Furthermore, a direct comparison using microsatellite markers would not be possible because the same markers are not shared by both species (TWJ Garner, unpublished data). Nevertheless, to investigate genetic variation at the broader geographic scale across Europe in S. stercoraria, we are currently conducting 
Table 1 Geographic coordinates, altitude, number of alleles (top) and gene diversity (bottom) for each locus and Scathophaga stercoraria population

\begin{tabular}{|c|c|c|c|c|c|c|c|c|c|}
\hline \multirow[t]{2}{*}{ Population } & \multirow{2}{*}{$\begin{array}{c}\text { Location } \\
\text { Latitude/Longitude }\end{array}$} & \multirow{2}{*}{$\begin{array}{l}\text { Altitude } \\
(\mathrm{m})\end{array}$} & \multicolumn{7}{|c|}{ Loci } \\
\hline & & & $M P I$ & G3PDH & GPI & $D I A$ & PGM & $H B D H$ & Total \\
\hline \multirow[t]{2}{*}{ Aecherlipass } & $46^{\circ} 52^{\prime} \mathrm{N} / 8^{\circ} 21^{\prime} \mathrm{E}$ & 1400 & 2 & 1 & 1 & 2 & 1 & 2 & 9 \\
\hline & & & 0.333 & 0 & 0 & 0.464 & 0 & 0.125 & 0.154 \\
\hline \multirow{2}{*}{ Arisdorf } & $47^{\circ} 31^{\prime} \mathrm{N} / 7^{\circ} 46^{\prime} \mathrm{E}$ & 350 & 2 & 1 & 1 & 2 & 2 & 1 & 9 \\
\hline & & & 0.200 & 0 & 0 & 0.167 & 0.143 & 0 & 0.085 \\
\hline \multirow[t]{2}{*}{ Boudevilliers } & $47^{\circ} 01^{\prime} \mathrm{N} / 6^{\circ} 55^{\prime} \mathrm{E}$ & 754 & 3 & 1 & 1 & 3 & 2 & 2 & 12 \\
\hline & & & 0.446 & 0 & 0 & 0.339 & 0.125 & 0.125 & 0.173 \\
\hline \multirow[t]{2}{*}{ Brüschwil } & $47^{\circ} 33^{\prime} \mathrm{N} / 9^{\circ} 19^{\prime} \mathrm{E}$ & 453 & 2 & 1 & 2 & 2 & 3 & 2 & 12 \\
\hline & & & 0.500 & 0 & 0.125 & 0.232 & 0.241 & 0.125 & 0.204 \\
\hline \multirow[t]{2}{*}{ Bulle } & $46^{\circ} 37^{\prime} \mathrm{N} / 7^{\circ} 04^{\prime} \mathrm{E}$ & 770 & 2 & 1 & 1 & 2 & 2 & 1 & 9 \\
\hline & & & 0.357 & 0 & 0 & 0.524 & 0.143 & 0 & 0.171 \\
\hline \multirow[t]{2}{*}{ Cadagno } & $46^{\circ} 45^{\prime} \mathrm{N} / 8^{\circ} 44^{\prime} \mathrm{E}$ & 1950 & 2 & 1 & 1 & 2 & 1 & 1 & 8 \\
\hline & & & 0.321 & 0 & 0 & 0.417 & 0 & 0 & 0.123 \\
\hline \multirow[t]{2}{*}{ Chur } & $46^{\circ} 52^{\prime} \mathrm{N} / 9^{\circ} 32^{\prime} \mathrm{E}$ & 600 & 2 & 2 & 1 & 3 & 2 & 2 & 12 \\
\hline & & & 0.464 & 0.125 & 0 & 0.589 & 0.125 & 0.125 & 0.238 \\
\hline Col de la Croix & $46^{\circ} 19^{\prime} \mathrm{N} / 7^{\circ} 04^{\prime} \mathrm{E}$ & 1750 & 1 & 1 & 1 & 3 & 2 & 1 & 9 \\
\hline & & & 0 & 0 & 0 & 0.274 & 0.232 & 0 & 0.084 \\
\hline Engelberg & $46^{\circ} 49^{\prime} \mathrm{N} / 8^{\circ} 25^{\prime} \mathrm{E}$ & 1003 & 3 & 1 & 2 & 2 & 1 & 1 & 10 \\
\hline & & & 0.482 & 0 & 0.125 & 0.321 & 0 & 0 & 0.155 \\
\hline Fehraltorf & $47^{\circ} 23^{\prime} \mathrm{N} / 8^{\circ} 45^{\prime} \mathrm{E}$ & 536 & 3 & 1 & 1 & 2 & 3 & 1 & 11 \\
\hline & & & 0.527 & 0 & 0 & 0.482 & 0.241 & 0 & 0.208 \\
\hline Flüelapass & $46^{\circ} 46^{\prime} \mathrm{N} / 9^{\circ} 57^{\prime} \mathrm{E}$ & 1900 & 2 & 1 & 1 & 4 & 3 & 2 & 13 \\
\hline & & & 0.250 & 0 & 0 & 0.518 & 0.274 & 0.125 & 0.195 \\
\hline Furkapass & $46^{\circ} 34^{\prime} \mathrm{N} / 8^{\circ} 25^{\prime} \mathrm{E}$ & 2430 & 2 & 1 & 1 & 2 & 2 & 1 & 9 \\
\hline & & & 0.464 & 0 & 0 & 0.500 & 0.125 & 0 & 0.182 \\
\hline Gilbach & $46^{\circ} 29^{\prime} \mathrm{N} / 7^{\circ} 34^{\prime} \mathrm{E}$ & 1439 & 2 & 1 & 1 & 3 & 2 & 1 & 10 \\
\hline & & & 0.350 & 0 & 0 & 0.241 & 0.125 & 0 & 0.119 \\
\hline Hoher Kasten & $47^{\circ} 17^{\prime} \mathrm{N} / 9^{\circ} 26^{\prime} \mathrm{E}$ & 1700 & 2 & 1 & 1 & 2 & 3 & 1 & 10 \\
\hline & & & 0.262 & 0 & 0 & 0.143 & 0.357 & 0 & 0.127 \\
\hline Jaunpass & $46^{\circ} 36^{\prime} \mathrm{N} / 7^{\circ} 21^{\prime} \mathrm{E}$ & 1400 & 2 & 1 & 1 & 2 & 3 & 1 & 10 \\
\hline & & & 0.300 & 0 & 0 & 0.500 & 0.488 & 0 & 0.215 \\
\hline Julierpass & $46^{\circ} 30^{\prime} \mathrm{N} / 9^{\circ} 45^{\prime} \mathrm{E}$ & 2100 & 2 & 1 & 1 & 2 & 3 & 2 & 11 \\
\hline & & & 0.125 & 0 & 0 & 0.500 & 0.286 & 0.143 & 0.176 \\
\hline Klausenpass & $46^{\circ} 52^{\prime} \mathrm{N} / 8^{\circ} 52^{\prime} \mathrm{E}$ & 1750 & 2 & 1 & 1 & 2 & 4 & 1 & 11 \\
\hline & & & 0.411 & 0 & 0 & 0.464 & 0.438 & 0 & 0.219 \\
\hline Netstal & $47^{\circ} 05^{\prime} \mathrm{N} / 9^{\circ} 04^{\prime} \mathrm{E}$ & 461 & 2 & 1 & 1 & 2 & 3 & 1 & 10 \\
\hline & & & 0.321 & 0 & 0 & 0.250 & 0.241 & 0 & 0.135 \\
\hline Nussbaumen & $47^{\circ} 28^{\prime} \mathrm{N} / 8^{\circ} 19^{\prime} \mathrm{E}$ & 450 & 1 & 1 & 2 & 2 & 3 & 1 & 10 \\
\hline & & & 0 & 0 & 0.125 & 0.429 & 0.518 & 0 & 0.179 \\
\hline Oberalppass & $46^{\circ} 39^{\prime} \mathrm{N} / 8^{\circ} 35^{\prime} \mathrm{E}$ & 1850 & 4 & 1 & 1 & 2 & 3 & 1 & 12 \\
\hline & & & 0.667 & 0 & 0 & 0.464 & 0.348 & 0 & 0.247 \\
\hline Parpan & $46^{\circ} 47^{\prime} \mathrm{N} / 9^{\circ} 34^{\prime} \mathrm{E}$ & 1490 & 2 & 1 & 1 & 3 & 2 & 1 & 10 \\
\hline & & & 0.533 & 0 & 0 & 0.517 & 0.125 & 0 & 0.196 \\
\hline Pragelpass & $46^{\circ} 59^{\prime} \mathrm{N} / 8^{\circ} 53^{\prime} \mathrm{E}$ & 1560 & 2 & 1 & 1 & 3 & 2 & 4 & 13 \\
\hline & & & 0.232 & 0 & 0 & 0.545 & 0.250 & 0.348 & 0.229 \\
\hline Prês d'Orvin & $47^{\circ} 10^{\prime} \mathrm{N} / 7^{\circ} 13^{\prime} \mathrm{E}$ & 1100 & 3 & 1 & 2 & 3 & 2 & 1 & 12 \\
\hline & & & 0.524 & 0 & 0.232 & 0.491 & 0.125 & 0 & 0.229 \\
\hline Reichenbach & $46^{\circ} 38^{\prime} \mathrm{N} / 7^{\circ} 42^{\prime} \mathrm{E}$ & 706 & 2 & 1 & 1 & 2 & 2 & 1 & 9 \\
\hline & & & 0.381 & 0 & 0 & 0.232 & 0.125 & 0 & 0.123 \\
\hline Rigi & $47^{\circ} 03^{\prime} \mathrm{N} / 8^{\circ} 33^{\prime} \mathrm{E}$ & 1604 & 2 & 1 & 1 & 3 & 3 & 1 & 11 \\
\hline & & & 0.411 & 0 & 0 & 0.274 & 0.348 & 0 & 0.172 \\
\hline Roggen & $47^{\circ} 18^{\prime} \mathrm{N} / 7^{\circ} 43^{\prime} \mathrm{E}$ & 810 & 2 & 1 & 1 & 2 & 3 & 2 & 11 \\
\hline & & & 0.300 & 0 & 0 & 0.500 & 0.405 & 0.143 & 0.225 \\
\hline Schwarzenburg & $46^{\circ} 49^{\prime} \mathrm{N} / 7^{\circ} 21^{\prime} \mathrm{E}$ & 792 & 2 & 1 & 2 & 2 & 2 & 2 & 11 \\
\hline & & & 0.500 & 0 & 0.143 & 0.262 & 0.143 & 0.143 & 0.199 \\
\hline Sils Maria & $46^{\circ} 27^{\prime} \mathrm{N} / 9^{\circ} 46^{\prime} \mathrm{E}$ & 1817 & 3 & 2 & 1 & 3 & 2 & 1 & 12 \\
\hline & & & 0.571 & 0.143 & 0 & 0.536 & 0.125 & 0 & 0.229 \\
\hline Tann & $47^{\circ} 13^{\prime} \mathrm{N} / 8^{\circ} 12^{\prime} \mathrm{E}$ & 666 & 2 & 1 & 1 & 2 & 2 & 2 & 10 \\
\hline & & & 0.411 & 0 & 0 & 0.464 & 0.125 & 0.143 & 0.191 \\
\hline Truttikon I & $47^{\circ} 38^{\prime} \mathrm{N} / 8^{\circ} 45^{\prime} \mathrm{E}$ & 472 & 2 & 1 & 1 & 2 & 1 & 1 & 8 \\
\hline & & & 0.350 & 0 & 0 & $0 . \overline{5} 00$ & 0 & 0 & 0.142 \\
\hline Truttikon II & $47^{\circ} 38^{\prime} \mathrm{N} / 8^{\circ} 45^{\prime} \mathrm{E}$ & 472 & 2 & 1 & 1 & 2 & 4 & 1 & 11 \\
\hline & & & 0.143 & 0 & 0 & 0.357 & 0.393 & 0 & 0.149 \\
\hline Urnerboden & $46^{\circ} 53^{\prime} \mathrm{N} / 8^{\circ} 55^{\prime} \mathrm{E}$ & 1389 & 2 & 1 & 1 & 2 & 1 & 1 & 8 \\
\hline & & & 0.321 & 0 & 0 & 0.339 & 0 & 0 & 0.110 \\
\hline
\end{tabular}


Table 1 Continued

\begin{tabular}{|c|c|c|c|c|c|c|c|c|c|}
\hline \multirow[t]{2}{*}{ Population } & \multirow{2}{*}{$\begin{array}{c}\text { Location } \\
\text { Latitude/Longitude }\end{array}$} & \multirow{2}{*}{$\begin{array}{l}\text { Altitude } \\
(\mathrm{m})\end{array}$} & \multicolumn{7}{|c|}{ Loci } \\
\hline & & & $M P I$ & G3PDH & GPI & $D I A$ & PGM & $H B D H$ & Total \\
\hline \multirow[t]{2}{*}{ Wangenried } & $47^{\circ} 14^{\prime} \mathrm{N} / 7^{\circ} 40^{\prime} \mathrm{E}$ & 473 & 2 & 1 & 1 & 2 & 3 & 2 & 11 \\
\hline & & & 0.393 & 0 & 0 & 0.518 & 0.339 & 0.125 & 0.229 \\
\hline \multirow[t]{2}{*}{ Wasserauen } & $47^{\circ} 17^{\prime} \mathrm{N} / 9^{\circ} 26^{\prime} \mathrm{E}$ & 872 & 2 & 1 & 1 & 2 & 2 & 1 & 9 \\
\hline & & & 0.452 & 0 & 0 & 0.357 & 0.125 & 0 & 0.156 \\
\hline \multirow[t]{2}{*}{ Average } & - & - & 2.15 & 1.06 & 1.15 & 2.32 & 2.32 & 1.38 & 10.38 \\
\hline & & & 0.362 & 0.008 & 0.022 & 0.403 & 0.208 & 0.049 & \\
\hline
\end{tabular}

Table 2 F-statistics (mean \pm SE) for each locus and for all loci combined for Scathophaga stercoraria and Sepsis cynipsea

\begin{tabular}{|c|c|c|c|c|}
\hline Species & Locus & $F_{I T}$ & $F_{S T}$ & $F_{I S}$ \\
\hline \multirow[t]{2}{*}{ S. stercoraria } & $\begin{array}{l}\text { MPI } \\
\text { G3PDH } \\
\text { GPI } \\
\text { DIA } \\
\text { PGM } \\
\text { HBDH }\end{array}$ & $\begin{aligned} 0.076 & \pm 0.059 \\
-0.002 & \pm 0.001 \\
-0.008 & \pm 0.004 \\
-0.035 & \pm 0.054 \\
0.166 & \pm 0.063^{* * *} \\
-0.016 & \pm 0.005\end{aligned}$ & $\begin{array}{r}-0.010 \pm 0.018 \\
-0.001 \pm 0.007 \\
0.021 \pm 0.024 \\
0.010 \pm 0.014 \\
-0.008 \pm 0.012 \\
0.003 \pm 0.015\end{array}$ & $\begin{aligned} 0.086 & \pm 0.062 \\
-0.001 & \pm 0.007 \\
-0.029 & \pm 0.025 \\
-0.045 & \pm 0.060 \\
0.173 & \pm 0.064^{* * * *} \\
-0.018 & \pm 0.016\end{aligned}$ \\
\hline & All loci & $0.037 \pm 0.055$ & $0.000 \pm 0.008$ & $0.038 \pm 0.062$ \\
\hline \multirow[t]{2}{*}{ S. cynipsea } & $\begin{array}{l}\text { MPI } \\
\text { G3PDH } \\
\text { GPI } \\
\text { DIA } \\
\text { PGM } \\
\text { HBDH } \\
\text { HK } \\
\text { HKXY } \\
\text { 6PGDH } \\
\text { MDH }\end{array}$ & $\begin{aligned} 0.142 & \pm 0.044^{* * * *} \\
0.000 & \pm 0.000 \\
-0.016 & \pm 0.005 \\
0.129 & \pm 0.059^{*} \\
0.544 & \pm 0.226^{* * *} \\
0.019 & \pm 0.058 \\
-0.002 & \pm 0.002 \\
0.170 & \pm 0.059^{* *} \\
0.106 & \pm 0.074^{*} \\
0.383 & \pm 0.253^{* * * *}\end{aligned}$ & $\begin{aligned} 0.029 & \pm 0.013^{* *} \\
-0.003 & \pm 0.002 \\
0.004 & \pm 0.012 \\
0.003 & \pm 0.014 \\
0.010 & \pm 0.018 \\
0.008 & \pm 0.017 \\
-0.004 & \pm 0.002 \\
0.020 & \pm 0.025 \\
0.035 & \pm 0.024 \\
0.252 & \pm 0.121^{* * *}\end{aligned}$ & $\begin{array}{l}0.126 \pm 0.044^{* * *} \\
0.003 \pm 0.002 \\
-0.020 \pm 0.013 \\
0.126 \pm 0.062^{*} \\
0.539 \pm 0.231^{* *} \\
0.012 \pm 0.065 \\
0.001 \pm 0.001 \\
0.154 \pm 0.065^{*} \\
0.073 \pm 0.071 \\
0.242 \pm 0.410^{*}\end{array}$ \\
\hline & All loci & $0.139 \pm 0.020^{* * *}$ & $0.025 \pm 0.010^{* * *}$ & $0.117 \pm 0.018^{* * *}$ \\
\hline
\end{tabular}

${ }^{*} P<0.05,{ }^{* *} P<0.01,{ }^{* * *} P<0.001$.

further studies at the allozyme and finer scale DNA levels.

Whereas $F_{\mathrm{ST}}$ was low and largely non-significant, we found considerable within-population heterozygote deficiency, ie, significant $F_{\mathrm{IS}}$, for several loci and overall in S. cynipsea. In S. stercoraria this occurred only for PGM. Significant $F_{\text {IS }}$ may be caused by null alleles that do not show up on the gel. Alternatively, substructuring within a pasture may result from inbreeding, non-random mating or reproductive failure of heterozygote individuals, but we have no direct evidence for any of these mechanisms from the field or the lab. In S. stercoraria, PGM is a highly polymorphic locus that has been implicated in cryptic female choice (Ward, 1998, 2000) and shows systematic seasonal and temperature variation (Kraushaar, 1994; Jann, 1997). It is thus possible that PGM may not be neutral but subject to (thermal) selection (eg, Watt, 1977, 1983; Watt et al, 1985; Eanes, 1999), which is another potential explanation for deviations from Hardy-Weinberg equilibrium. Selection may equally be invoked in explaining significant $F_{\mathrm{IS}}$ in S. cynipsea, but in this species we have no further evidence corroborating this supposition (except perhaps for $\mathrm{MDH}$; see below), so we consider this unlikely.

We also investigated altitudinal genetic variation and obtained some evidence that gene diversity increases at higher altitudes in S. cynipsea. This effect was primarily mediated by MDH (in addition to MPI and DIA). MDH was completely monomorphic in S. stercoraria, whereas in S. cynipsea a second allele was present only in populations above $1000 \mathrm{~m}$. The latter was also true for the slowest allele of the locus DIA. For the warm-adapted S. cynipsea, the colder and harsher high altitude pastures should be the more stressful habitats (see Introduction). For example, development time is much prolonged at cooler temperatures (Blanckenhorn, 1997a), increasing the time larvae are exposed to mortality factors. In contrast, gene diversity was not greater in lowland S. stercoraria, as we had expected based on the same reasoning. Hot weather results in high mortality in this species (Ward and Simmons, 1990; Blanckenhorn, 1998a), and lowland habitats are considerably hotter on average (Blanckenhorn, 1997a): S. stercoraria should therefore prefer the cooler, high altitude habitats (Gorodkov, 1984). However, (re)colonization of high altitude pastures is only possible via the lowlands, so recurrent migration should homogenize genetic variation with regard to altitude in this species. This cannot necessarily be expected in S. cynipsea, which should migrate only occasionally (perhaps by accident) from the preferred lowlands (the population sources) to the highlands (the population sinks). However, since we found no difference in the 
Table 3 Geographic coordinates, altitude, number of alleles (top) and gene diversity (bottom) for each locus and Sepsis cynipsea population

\begin{tabular}{|c|c|c|c|c|c|c|c|c|c|c|c|c|c|}
\hline \multirow[t]{2}{*}{ Population } & \multirow{2}{*}{$\begin{array}{c}\text { Location } \\
\text { Latitude/Longitude }\end{array}$} & \multirow{2}{*}{$\begin{array}{l}\text { Altitude } \\
(m)\end{array}$} & \multicolumn{11}{|c|}{ Loci } \\
\hline & & & $M P I$ & G3PDH & GPI & $D I A$ & $P G M$ & $H B D H$ & $H K$ & HKXY & 6PGDH & $M D H$ & Total \\
\hline \multirow[t]{2}{*}{ Aecherlipass } & $46^{\circ} 52^{\prime} \mathrm{N} / 8^{\circ} 21^{\prime} \mathrm{E}$ & 1400 & 5 & 1 & 2 & 2 & 1 & 2 & 1 & 2 & 3 & 1 & 20 \\
\hline & & & 0.770 & 0 & 0.232 & 0.393 & 0 & $0 . \overline{4} 00$ & 0 & 0.536 & 0.607 & 0 & 0.294 \\
\hline \multirow{2}{*}{ Arolla } & $46^{\circ} 02^{\prime} \mathrm{N} / 7^{\circ} 29^{\prime} \mathrm{E}$ & 2000 & 5 & 1 & 1 & 4 & 2 & 2 & 1 & 2 & 2 & 1 & 21 \\
\hline & & & 0.845 & 0 & 0 & 0.643 & 0.125 & 0.500 & 0 & 0.429 & 0.500 & 0 & 0.304 \\
\hline \multirow{2}{*}{ Beromünster } & $47^{\circ} 13^{\prime} \mathrm{N} / 8^{\circ} 12^{\prime} \mathrm{E}$ & 666 & 6 & 1 & 1 & 2 & 2 & 2 & 1 & 2 & 2 & 1 & 20 \\
\hline & & & 0.848 & 0 & 0 & 0.500 & 0.125 & 0.262 & 0 & 0.357 & 0.518 & 0 & 0.261 \\
\hline \multirow{2}{*}{ Brülisau } & $47^{\circ} 17^{\prime} \mathrm{N} / 9^{\circ} 27^{\prime} \mathrm{E}$ & 790 & 4 & 1 & 2 & 2 & 1 & 3 & 1 & 2 & 2 & 1 & 19 \\
\hline & & & 0.759 & 0 & 0.125 & 0.393 & 0 & 0.339 & 0 & 0.518 & 0.411 & 0 & 0.255 \\
\hline \multirow[t]{2}{*}{ Bulle } & $46^{\circ} 37^{\prime} \mathrm{N} / 7^{\circ} 04^{\prime} \mathrm{E}$ & 770 & 5 & 1 & 1 & 3 & 1 & 2 & 1 & 2 & 3 & 1 & 20 \\
\hline & & & 0.726 & 0 & 0 & 0.524 & 0 & 0.143 & 0 & 0.500 & 0.583 & 0 & 0.248 \\
\hline \multirow[t]{2}{*}{ Chur } & $46^{\circ} 52^{\prime} \mathrm{N} / 9^{\circ} 32^{\prime} \mathrm{E}$ & 600 & 6 & 1 & 1 & 2 & 1 & 2 & 1 & 3 & 2 & 1 & 20 \\
\hline & & & 0.804 & 0 & 0 & 0.393 & 0 & 0.400 & 0 & 0.545 & 0.500 & 0 & 0.264 \\
\hline \multirow[t]{2}{*}{ Col de la Croix } & $46^{\circ} 19^{\prime} \mathrm{N} / 7^{\circ} 04^{\prime} \mathrm{E}$ & 1750 & 7 & 1 & 1 & 3 & 1 & 2 & 1 & 3 & 2 & 2 & 23 \\
\hline & & & 0.902 & 0 & 0 & 0.688 & 0 & 0.232 & 0 & 0.625 & 0.533 & 0.250 & 0.323 \\
\hline Engelberg & $46^{\circ} 49^{\prime} \mathrm{N} / 8^{\circ} 25^{\prime} \mathrm{E}$ & 1003 & 6 & 1 & 2 & 2 & 1 & 1 & 1 & 2 & 3 & 2 & 21 \\
\hline & & & 0.821 & 0 & 0.125 & 0.536 & 0 & 0 & 0 & 0.500 & 0.616 & 0.250 & 0.285 \\
\hline Flüelapass & $46^{\circ} 46^{\prime} \mathrm{N} / 9^{\circ} 57^{\prime} \mathrm{E}$ & 1900 & 6 & 1 & 1 & 2 & 1 & 3 & 1 & 2 & 2 & 1 & 20 \\
\hline & & & 0.839 & 0 & 0 & 0.500 & 0 & 0.420 & 0 & 0.571 & 0.518 & 0 & 0.285 \\
\hline Flumserberge & $47^{\circ} 09^{\prime} \mathrm{N} / 9^{\circ} 15^{\prime} \mathrm{E}$ & 1230 & 5 & 1 & 1 & 2 & 1 & 2 & 1 & 3 & 2 & 2 & 20 \\
\hline & & & 0.777 & 0 & 0 & 0.411 & 0 & 0.350 & 0 & 0.554 & 0.300 & 0.500 & 0.289 \\
\hline Hoher Kasten & $47^{\circ} 17^{\prime} \mathrm{N} / 9^{\circ} 26^{\prime} \mathrm{E}$ & 1700 & 5 & 1 & 1 & 3 & 1 & 3 & 1 & 2 & 2 & 1 & 20 \\
\hline & & & 0.804 & 0 & 0 & 0.598 & 0 & 0.241 & 0 & 0.232 & 0.518 & 0 & 0.239 \\
\hline Netstal & $47^{\circ} 05^{\prime} \mathrm{N} / 9^{\circ} 04^{\prime} \mathrm{E}$ & 461 & 4 & 1 & 1 & 3 & 1 & 3 & 1 & 3 & 3 & 1 & 21 \\
\hline & & & 0.738 & 0 & 0 & 0.482 & 0 & 0.241 & 0 & 0.607 & 0.482 & 0 & 0.255 \\
\hline Novazzaro & $46^{\circ} 01^{\prime} \mathrm{N} / 8^{\circ} 57^{\prime} \mathrm{E}$ & 300 & 5 & 1 & 2 & 3 & 1 & 2 & 1 & 2 & 3 & 1 & 21 \\
\hline & & & 0.804 & 0 & 0.125 & 0.661 & 0 & 0.232 & 0 & 0.393 & 0.563 & 0 & 0.278 \\
\hline Nussbaumen & $47^{\circ} 28^{\prime} \mathrm{N} 8^{\circ} 19^{\prime} \mathrm{E}$ & 450 & 5 & 1 & 2 & 3 & 1 & 4 & 1 & 3 & 2 & 1 & 23 \\
\hline & & & 0.833 & 0 & 0.125 & 0.545 & 0 & 0.348 & 0 & 0.571 & $0 . \overline{4} 29$ & 0 & 0.285 \\
\hline Oberalppass & $46^{\circ} 39^{\prime} \mathrm{N} / 8^{\circ} 35^{\prime} \mathrm{E}$ & 1850 & 5 & 1 & 1 & 3 & 1 & 2 & 1 & 3 & 3 & 2 & 22 \\
\hline & & & 0.762 & 0 & 0 & 0.583 & 0 & 0.125 & 0 & 0.625 & 0.550 & 0.125 & 0.277 \\
\hline Parpan & $46^{\circ} 47^{\prime} \mathrm{N} / 9^{\circ} 34^{\prime} \mathrm{E}$ & 1490 & 5 & 1 & 2 & 4 & 2 & 2 & 1 & 3 & 2 & 1 & 23 \\
\hline & & & 0.821 & 0 & 0.125 & 0.759 & 0.250 & 0.232 & 0 & 0.661 & 0.464 & 0 & 0.331 \\
\hline Pragelpass & $46^{\circ} 59^{\prime} \mathrm{N} / 8^{\circ} 53^{\prime} \mathrm{E}$ & 1560 & 5 & 1 & 1 & 3 & 1 & 2 & 1 & 3 & 2 & 2 & 21 \\
\hline & & & 0.817 & 0 & 0 & 0.571 & 0 & 0.167 & 0 & 0.589 & 0.500 & 0.500 & 0.314 \\
\hline Prês d'Orvin & $47^{\circ} 10^{\prime} \mathrm{N} / 7^{\circ} 13^{\prime} \mathrm{E}$ & 1100 & 7 & 1 & 1 & 3 & 1 & 1 & 1 & 2 & 2 & 1 & 20 \\
\hline & & & 0.830 & 0 & 0 & 0.438 & 0 & 0 & 0 & 0.518 & 0.536 & 0 & 0.232 \\
\hline Quartino & $46^{\circ} 01^{\prime} \mathrm{N} / 8^{\circ} 57^{\prime} \mathrm{E}$ & 250 & 5 & 1 & 1 & 2 & 1 & 3 & 1 & 2 & 3 & 1 & 20 \\
\hline & & & 0.795 & 0 & 0 & 0.536 & 0 & 0.241 & 0 & $0 . \overline{4} 76$ & 0.536 & 0 & 0.258 \\
\hline Reichenbach & $46^{\circ} 38^{\prime} \mathrm{N} / 7^{\circ} 42^{\prime} \mathrm{E}$ & 706 & 5 & 1 & 2 & 2 & 1 & 3 & 2 & 2 & 3 & 1 & 21 \\
\hline & & & 0.786 & 0 & 0.125 & 0.554 & 0 & 0.286 & 0.125 & 0.536 & 0.598 & 0 & 0.301 \\
\hline Roggen & $47^{\circ} 18^{\prime} \mathrm{N} / 7^{\circ} 43^{\prime} \mathrm{E}$ & 800 & 5 & 1 & 1 & 2 & 3 & 3 & 1 & 2 & 4 & 1 & 24 \\
\hline & & & 0.839 & 0 & 0 & 0.500 & 0.357 & 0.339 & 0 & 0.464 & 0.652 & 0 & 0.315 \\
\hline Romanshorn & $47^{\circ} 34^{\prime} \mathrm{N} / 9^{\circ} 23^{\prime} \mathrm{E}$ & 399 & 4 & 1 & 1 & 3 & 1 & 2 & 1 & 3 & 3 & 1 & 20 \\
\hline & & & 0.741 & 0 & 0 & 0.580 & 0 & 0.125 & 0 & 0.598 & 0.560 & 0 & 0.260 \\
\hline Samedan & $46^{\circ} 33^{\prime} \mathrm{N} / 9^{\circ} 53^{\prime} \mathrm{E}$ & 1721 & 5 & 1 & 1 & 3 & 1 & 3 & 1 & 2 & 2 & 1 & 20 \\
\hline & & & 0.795 & 0 & 0 & 0.598 & 0 & 0.429 & 0 & 0.536 & 0.339 & 0 & 0.270 \\
\hline Schwarzenburg & $46^{\circ} 49^{\prime} \mathrm{N} / 7^{\circ} 21^{\prime} \mathrm{E}$ & 792 & 6 & 1 & 1 & 2 & 1 & 2 & 1 & 2 & 2 & 1 & 19 \\
\hline & & & 0.830 & 0 & 0 & 0.518 & 0 & 0.125 & 0 & 0.567 & 0.518 & 0 & 0.256 \\
\hline St. Gotthard & $46^{\circ} 15^{\prime} \mathrm{N} / 8^{\circ} 02^{\prime} \mathrm{E}$ & 1760 & 4 & 1 & 1 & 3 & 2 & 2 & 1 & 3 & 2 & 2 & 21 \\
\hline & & & 0.800 & 0 & 0 & 0.375 & 0.200 & 0.200 & 0 & 0.600 & 0.500 & 0.400 & 0.308 \\
\hline Truttikon & $47^{\circ} 38^{\prime} \mathrm{N} / 8^{\circ} 45^{\prime} \mathrm{E}$ & 472 & 3 & 1 & 3 & 3 & 1 & 2 & 1 & 2 & 2 & 1 & 19 \\
\hline & & & 0.667 & 0 & 0.241 & 0.500 & 0 & 0.339 & 0 & 0.500 & 0.554 & 0 & 0.280 \\
\hline Urnerboden & $46^{\circ} 53^{\prime} \mathrm{N} / 8^{\circ} 55^{\prime} \mathrm{E}$ & 1389 & 5 & 1 & 2 & 3 & 1 & 3 & 2 & 2 & 3 & 2 & 24 \\
\hline & & & 0.750 & 0 & 0.125 & 0.643 & 0 & 0.429 & 0.125 & 0.536 & 0.571 & 0.250 & 0.343 \\
\hline Vue des Alpes & $47^{\circ} 01^{\prime} \mathrm{N} / 6^{\circ} 55^{\prime} \mathrm{E}$ & 1283 & 6 & 2 & 1 & 3 & 1 & 3 & 1 & 2 & 2 & 2 & 23 \\
\hline & & & 0.848 & 0.125 & 0 & 0.518 & 0 & 0.554 & 0 & 0.554 & 0.232 & 0.250 & 0.308 \\
\hline Wangenried & $47^{\circ} 14^{\prime} \mathrm{N} / 7^{\circ} 40^{\prime} \mathrm{E}$ & 473 & 5 & 1 & 1 & 2 & 1 & 2 & 1 & 2 & 2 & 1 & 18 \\
\hline & & & 0.786 & 0 & 0 & 0.482 & 0 & 0.125 & 0 & $0 . \overline{4} 64$ & 0.500 & 0 & 0.236 \\
\hline Average & - & - & 5.18 & 1.03 & 1.34 & 2.66 & 1.21 & 2.34 & 1.07 & 2.34 & 2.41 & 1.28 & 20.86 \\
\hline & & & 0.799 & 0.004 & 0.046 & 0.532 & 0.036 & 0.270 & 0.009 & 0.523 & 0.506 & 0.087 & \\
\hline
\end{tabular}

degree of geographic differentiation between the two species, and thus presumably in the extent of gene flow among populations, (stronger) selection on particular rare alleles may instead better explain the altitudinal increase in allozyme variation in S. cynipsea. Here we might have found a candidate for a temperature-dependent enzyme perhaps allowing its bearer to function better at lower temperatures. MDH is a major enzyme of the citric acid cycle and therefore influences energy provision and thus major life functions of an individual. This 

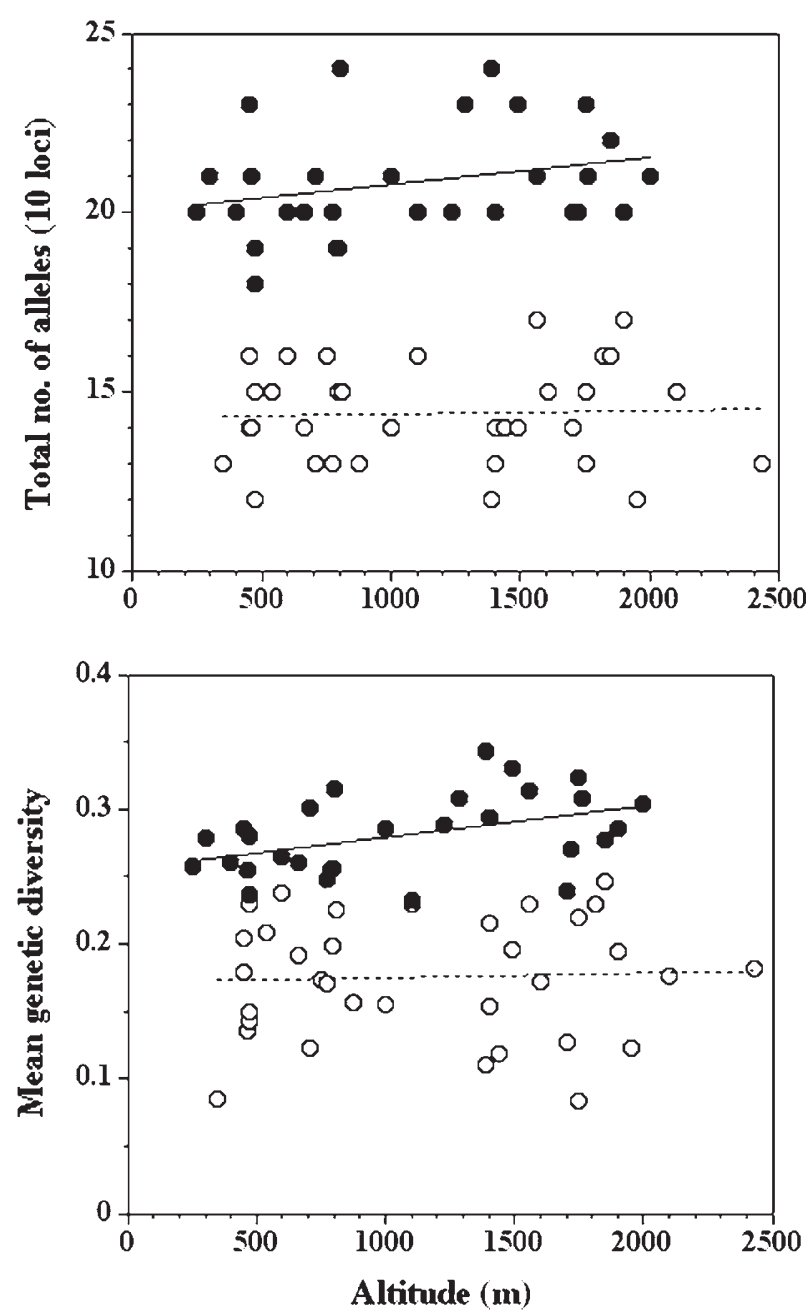

Figure 1 The total number of alleles at the same 10 loci (top) and the mean genetic diversity of six and 10 (respectively) polymorphic loci (bottom) for 34 and 29 Swiss populations of the dung flies Scathophaga stercoraria (open circles and dashed lines) and Sepsis cynipsea (filled circles and solid lines) in relation to altitude.

would be consistent with the expectation that harsher, more stressful, environments can increase mutation rates (Hoffmann and Parsons, 1991) and may lead to particular alleles being favoured by selection because they have the corresponding temperature optima (cf. Watt, 1977, 1983; Watt et al,1985; Eanes, 1999). However, so far we have no direct evidence for these mechanisms, so they need to be investigated further.

\section{Acknowledgements}

We thank C Mühlhäuser for help with collecting flies, Jeannette Fanti for help in the laboratory, Paul Ward, Nicolas Perrin, Bob Martin and Trent Garner for comments, and the Swiss National Fund for funding this project.

\section{References}

Amano K (1983). Studies on the intraspecific competition in dung breeding flies. I. Effects of larval density on the yellow dung fly. Jpn J Sanit Zool 34: 165-175.
Berg EE, Hammrick JL (1997). Quantification of genetic diversity at allozyme loci. Can J For Res 27: 415-424.

Blanckenhorn WU (1997a). Altitudinal life history variation in the dung flies Scathophaga stercoraria and Sepsis cynipsea. Oecologia 109: 342-352.

Blanckenhorn WU (1997b). Effects of temperature on growth, development and diapause in the yellow dung fly - against all the rules? Oecologia 111: 318-324.

Blanckenhorn WU (1998a). Adaptive phenotypic plasticity in growth, development and body size in the yellow dung fly. Evolution 52: 1394-1407.

Blanckenhorn WU (1998b). Altitudinal adaptation in diapause responses in two spiecies of dung flies. Ecol Entomol 23: 1-8.

Blanckenhorn WU, Morf C, Mühlhäuser C, Reusch T (1999). Spatiotemporal variation in selection on body size in the dung fly Sepsis cynipsea. J Evol Biol 12: 563-576.

Blanckenhorn WU, Henseler C, Burkhard DU, Briegel H (2001). Summer decline in populations of the yellow dung fly: diapause or quiescence? Physiol Entomol 26: 260-265.

Eanes WF (1999). Analysis of selection on enzyme polymorphisms. Ann Rev Ecol Syst 30: 301-326.

Gibbons DS (1987). The causes of seasonal changes in numbers of the yellow dung fly, Scathophaga stercoraria (Diptera: Scathophagidae). Ecol Entomol 12: 173-185.

Gorodkov KB (1984). Scathophagidae. In: Soos A, Papp L (eds) Catalogue of Palaearctic Diptera, Elsevier: Amsterdam, pp 11-41.

Goudet J (1995). FSTAT V1.2. A computer program to calculate F-statistics. J Hered 86: 485-486.

Goudet J, Raymond M, de Meeüs T, Rousset F (1996). Testing differentiation in diploid populations. Genetics 144: 19331940.

Hammer O (1941). Biological and ecological investigations on flies associated with pasturing cattle and their excrement. Vidensk Medd Naturhist Foren Kobenhavn 105: 140-393.

Hoffmann AA, Parsons PA (1991). Evolutionary Genetics and Environmental Stress. Oxford University Press: Oxford.

Huey RB, Kingsolver JG (1989). Evolution of thermal sensitivity in ectotherms. Trends Ecol Evol 4: 131-135

Jann P (1997). Natürliche und sexuelle Selektion bei der gelben Mistfliege Scathophaga stercoraria (L.). PhD Thesis, University of Zürich.

Jann P, Blanckenhorn WU, Ward PI (2000). Temporal and microspatial variation in the intensities of natural and sexual selection in the yellow dung fly Scathophaga stercoraria. J Evol Biol 13: 927-938.

Kraushaar U, Blanckenhorn WU (2002). Population variation in sexual selection and its effect on body size allometry in two species of flies with contrasting sexual size dimorphism. Evolution 56: 307-321.

Kraushaar U (1994). Temperatur- und Feuchtigkeitsabhängigkeit der Allozyme von PGM und GPI bei Scathophaga stercoraria (L.). Diploma thesis, University of Zürich.

Manly B (1985). The Statistics of Natural Selection. Chapman and Hall: London.

Mantel N (1967). The detection of disease clustering and a generalised regression approach. Cancer Res 27: 209-220.

Meier R (1996). Larval morphology of the Sepsidae (Diptera: Sciomyzoidea), with a cladistic analysis using adult and larval characters. Bull Am Mus Nat Hist 228: 1-147.

Murphy RW, Sites JW, Buth DG, Haufler CH (1990). Proteins I: isozyme electrophoresis. In: Hillis DM, Moritz (eds) Molecular Systematics, Sinauer Associates: Sunderland, pp 45-126.

Parker GA (1970). The reproductive behaviour and the nature of sexual selection in Scathophaga stercoraria L. (Diptera: Schathophagidae) I. Diurnal and seasonal changes in population density around the site of mating and oviposition. $J$ Anim Ecol 39: 185-204.

Shaklee JB, Allendorf FW, Morizot DC, Whitt GS (1990). Gene nomenclature for protein-coding loci in fish. Trans Am Fish Soc 119: 2-15. 
Slatkin M (1993). Isolation by distance in equilibrium and nonequilibrium populations. Evolution 47: 264-279.

Ward PI (1998). A possible explanation for cryptic female choice in the yellow dung fly, Scathophaga stercoraria (L.). Ethology 104: 97-110.

Ward PI (2000). Cryptic female choice in the yellow dung fly Scathophaga stercoraria. Evolution 54: 1680-1686.

Ward PI, Simmons LW (1990). Short-term changes in numbers of the yellow dung fly Scathophaga stercoraria (Diptera: Scathophagidae). Ecol Entomol 15: 115-118.

Watt WB (1977). Adaptation at specific loci I. Natural selection on phosphoglucose isomerase of Colias butterflies: biochemical and population aspects. Genetics 87: 177-194.
Watt WB (1983). Adaption at specific loci. II. Democraphic and biochemical elements in the maintenance of the Colias PGI polymorphism. Genetics 103: 691-724.

Watt WB, Carter PA, Blower SM (1985). Adaption at specific loci: IV. Differential mating success among clycolytic allozyme genotypes of Colias butterflies. Genetics 109: 157-175.

Wright S (1943). Isolation by distance. Genetics 28: 114-138.

Wright S (1951). The genetical structure of populations. Ann Eugenics 15: 323-354

Zuska J, Pont AC (1984). Sepsidae. In: Soós A, Papp L (eds) Catalogue of Palaearctic Diptera, Elsevier: Amsterdam, pp 154-166. 